\title{
Pandemic Economics: Problems and Prospects
}

\author{
A. V. Fedotova* \\ Moscow Aviation Institute, Moscow, Russia \\ *e-mail: anastasya-nancy@bk.ru \\ Received July 12, 2021; revised July 12, 2021; accepted July 12, 2021
}

\begin{abstract}
The COVID-19 coronavirus poses a considerable and unexpected challenge to the global economy and the economy of each nation, even though specialists have repeatedly warned of a possible virus pandemic and the need for preparations. In the present work, the economic situation in pandemic conditions is analyzed in historical perspective. The associated problems and barriers are identified, and the potential impact on business processes is sketched. Possible approaches to improving the post-virus economy and the world as a whole are proposed.
\end{abstract}

Keywords: business processes, pandemic, global economy, current technology, prospects

DOI: $10.3103 / \mathrm{S} 1068798 X 22010075$

At the end of March 2020, more than two billion people around the world (in fact, every third person on the planet) found themselves in quarantine, creating a new set of economic conditions. The ultimate economic impact of the COVID-19 coronavirus will be measured in trillions of dollars.

This research addresses questions regarding the impact of the pandemic on human life. How will the economy be affected? What consequences are unavoidable?

(1) The pandemic has a severe impact on countries whose GDP depends on tourism. Rapid recovery of tourism is unlikely, because many small operators have already gone bankrupt.

(2) Transport companies will suffer with the drop in passenger traffic. Likewise, demand for fuel fell in the middle of 2020. The impact on global industry is most serious: in particular, in the auto and aircraft sectors, general manufacturing, and the production of machines and equipment for light industry and electronics. China and the European Union, which produce for export, are particularly vulnerable. China's vast domestic market, with appropriate stimulation of demand by financial and credit easements, may at least slow the decline in industrial output (and hence in trade and GDP), preventing a crisis. However, the European market has practically no scope for growth and cannot absorb domestic industrial output.

(3) Since 2020, the links between the state and business have strengthened. Because it sets rules and expects public goods (in terms of employment, taxes, environmental protection, and social development), the state is involved in business planning from the very beginning of each project. This is both good and bad: on the one hand, business may rely on support from the state in extraordinary times; on the other, business may expect more tracking, testing, and monitoring by the state.

(4) From the very beginning of the pandemic, the expectation has been that the world will be very different afterward. However, the changes will not necessarily all be negative: for example, the plague of 13461353 led to the emergence of modern capitalism. Some directions in which the world may move are already evident: biotechnology, digitization, global automation, etc. We will see a more online world: after their experiences during the pandemic, more people will want to work from home and will make purchases and conclude negotiations through the Internet.

\section{MATERIALS AND METHODS}

No matter how entrenched the virus may seem, sooner or later caseloads will decline and we will find ourselves in a post-virus world. The history of three major pandemics - the plague of Justinian, the Black Death, and the 1918 influenza outbreak-show that, despite the destruction wrought by deadly viruses, the economy remains highly adaptive [1].

In thinking about COVID-19, the following aspects of the economy must be taken into account: (a) the use of natural resources (resource-producing nations are in crisis); (b) a unified commodity market (globalization, extreme consumer demand); (c) the service economy (tourism, restaurants, infrastructure, etc.) [2].

The world today is a highly organized system. The impact of COVID-19 on stock exchanges was local at first but was soon followed by a global market crash, 
with swings of 3-7\%. Since then, there have been several other significant drops. Many enterprises of different types have closed, and the long quarantine has changed consumption patterns. A global recession is likely. Nevertheless, if businesses can intelligently anticipate growing demand, some industries may even grow.

Instead of economic development through maximum prowess in international trade, protectionism and local production with maximum added value are now important national goals. For large businesses, integrity of the production chain must be a priority. For small and medium-sized businesses, the main problem is the ability to pay wages and rent in an era of reduced or vanishing revenues. Business success will depend on the ability of management to quickly develop and implement solutions [3]. Rapid digitization is underway. Everything that can be converted to digital format and remotely accessed already has been or soon will be.

Digitization implies the predominant use of digital technology in the generation, analysis, transmission, storage, and visualization of information, by new technical measures and software, which are becoming economically and physically more accessible. In the European Community, the measures adopted to support digitization of the economy may be regarded as adequate and appropriate. They take account of the specifics of technological progress and are based on a systems approach and profound analytical developments [4].

For several reasons, it is difficult to assess the Russian economy and to make short-term forecasts.

(1) Russia role in the global market does not match that of China or the European Community. Its presence in the international financial market is no larger than a rounding error.

(2) Internal demand for commodities and products is low, because much of the population survives on small incomes. However, such demand will be important in Russia's economic recovery after the pandemic has abated.

The following industries may benefit significantly from the pandemic.

(1) Delivery services and product aggregators. During the quarantine, business can only survive through deliveries, online sales, and logistics. The quickest way to master this sales channel is to link up with product aggregators and delivery partners, which will help to develop B2B and B2C relationships (examples: Gett, Delivery Club, Yandex). Services have to adapt to new realities: restrictions on contact and cashless payments.

(2) Online learning. Even before, this industry had undergone stable development, to the tune of $\$ 74$ billion. The pandemic has prompted a sharp rise in interest, estimated at a $400 \%$ increase in customers. Many new customers may quickly be converted to long-term clients, with $20-30 \%$ increase in the revenues of such platforms. Public universities, schools, and preschools have also embraced distance learning.

(3) E-commerce. With consumers moving online, new advertising approaches are required. Before the pandemic, the prediction was that online commerce would outstrip traditional commerce by 2036, but that will certainly happen more quickly now. Digital marketing is already an integral component of business processes, out of necessity. Today, speed is an even higher priority. As consumers actively switch to online shopping, companies must grab their attention as quickly as possible so as to move them promptly to a sale, generating profit [5].

(4) Communications services. As the world switches to remote work, IT companies face loads they had not foreseen. Services for video communication and workspace organization provide the basic infrastructure for that transition and their revenues will grow accordingly. Digitization is critical in the era of global quarantine. Developments may be expected in artificial intelligence, robotization, and automation.

The automation of commerce permits optimization of expenditures and optimization of staff size. Retailers and manufacturers are investing in automation technologies: $41 \%$ of the participants in an EY survey reported that this was how they were preparing for life after the crisis. One innovation is robotic process automation (RPA), which relies not on physical robots but on virtual assistants, which automate individual tasks.

\section{RESULTS}

It is impossible to predict all the consequences of the COVID-19 virus, but the areas most affected can be identified by means of annual statistical data. As already noted, some sectors are benefitting from the pandemic. In that case, the digital transformation permits survival in the global economy and is essential for competitiveness.

Undoubtedly, we will witness a transition of business processes to a distributed model, without ties to a specific location. Analysis shows that RPA is not only a tool to accelerate company growth but will also provide support in a crisis. Those who are just embarking on the path to automation may find it difficult to analyze the impact of RPA on productivity. Accordingly, we will note some important points here.

(1) Tasks may be completed 20 times faster by RPA than by humans. (Repeated iteration of an algorithm does not induce fatigue.)

(2) Costs are reduced by automating laborious business processes in the front office and back office.

(3) The risk of errors in business processes is practically eliminated. Humans are freed from the need for continuous manual updating of files.

(4) RPA may be used in all sectors of the economy. 
In Russia, the economic transition from traditional resources (oil, gas, etc.) to the creation and development of IT infrastructure will create competition between existing market players [6]. Investment in digitization will undoubtedly improve economic efficiency and facilitate the development of a new model for the era after the pandemic.

Experience in many countries has confirmed the significant of state regulation and support for new digital technologies. In this context, digitization initiatives should be included in state industrial policy [7]. That will assist Russia in accelerating industrial growth, import substitution, and increasing labor productivity, for example.

Steps in this direction have already been taken: for example, following the decision of the Expert Council on Software at the Russian Ministry of Digital Development, Communications, and Mass Media, some companies have officially been included in the uniform register of Russian computer and database programs [6].

Thus, the introduction of new IT companies will assist other state companies in honoring production schedules and preparing quarterly reports. However, the new distributed model and the accompanying robotization may also increase unemployment. That will increase the demand for social benefits, and economic relations will become less capitalistic and more socialistic $[5,8]$.

Other potential downsides of digitization for the Russian economy and society are decrease in the total number of jobs and digital fraud, as noted in [2]. In that case, the primary goals should be maintaining stability (meeting the population's basic needs), ensuring an acceptable existence for most of the population (without overreliance on private funds), and maintaining tax revenues [9].

\section{CONCLUSIONS}

(1) Undoubtedly, combatting the COVID-19 pandemic is a worthwhile and very costly task. In addressing the pandemic, the state is changing the rules of the economy. It turns out that the following situation is possible: (1) shutdown of daily business activity; (2) limitation of the free motion of people and goods; (3) disruption of systems that have been in place for years and the creation of a state of uncertainty regarding practically all economic activity, with no chance of reliable forecasting.

(2) After the crisis, consequently, the model of stable business process will depend on proximity to the state. All of life will be transferred online, with significant acceleration of digitization. In this framework, the state will take long-term decisions that ensure funding in support of digital life $[10,11]$.
The simplicity and accessibility of robotic process automation (RPA) enable companies to quickly identify short-term survival strategies. Ultimately, such systems have advantages and disadvantages. However, unless such digital tools are employed, both business and the state will simply be globally uncompetitive, and the quality of life will suffer [7, 12, 13].

\section{REFERENCES}

1. Kochetkova, A.I. and Kochetkov, P.N., Osnovy upravleniya $v$ usloviyakh khaosa. Antikrizisnoe upravlenie. Uchebnoe posobie (Fundamentals of Management in Chaos: Crisis Management. Manual), Moscow: Yurait, 2019, part 1.

2. Zozulya, D.M. and Smolyar, Yu.V., Crisis benchmarking as an innovative tool for management of an organization in an unstable environment, Kreativnaya Ekon., 2019, vol. 13, no. 3, pp. 483-494.

3. Parshin, I., Pandemic as a stress test: which industries will develop due to the virus. https://www.rbc.ru/trends/industry/5e9034bf9a7947a07e906246. Accessed May 5, 2021.

4. Sabgieva, P.R., The global financial crisis: realities and ways out, Aktual'n. Vopr. Sovrem. Ekon. Global'nom Mire, 2019, no. 5, pp. 129-132.

5. Trotsenko, R., Post-crisis management: how a pandemic will change the world, government and business. https://www.rbc.ru/opinions/business/06/04/2020/ 5e8ad3e19a79474519df924d. Accessed April 20, 2021.

6. Volkova, A.A., Plotnikov, V.A., and Rukinov, M.V., Digital economy: phenomenon, problems, and risks of development, Upr. Konsul'tirovanie, 2019, no. 4, pp. 3-49.

7. Novikov, S.V., Lastochkina, V.V., and Solodova, A.D., Import substitution in digitalization, J. Phys.: Conf. Ser., 2020, vol. 1515, art. ID 032001.

8. Zaitsev, V.E., Digital economy as a subject of research: a review of publications, Vopr. Gos. Munitsip. Upr., 2019, no. 3, pp. 107-122.

9. Novikov, S.V., Lastochkina, V.V., and Solodova, A.D., Import substitution in the industrial sector: analysis and facts, IOP Conf. Ser.: Mater. Sci. Eng., 2019, vol. 537, art. ID 042056.

10. Pokrovskii, V.I., Infektsionnye bolezni v sovremennom mire: evolyutsiya, tekushchie i budushchie ugrozy (Infectious Diseases in the Modern World: Evolution, Current and Future Threats), Moscow: Med. Marketing. Agentstvo, 2018.

11. Novikov, S.V., Problems of the Russian economy integration in the sphere of high-tech global space, TEMJ., 2019, vol. 8, no. 1, pp. 207-210.

12. ElectroNeek Company official website. https://electroneek.ru. Accessed May 1, 2020.

13. Novikov, S.V., Data science and big data technologies role in the digital economy, TEM J., 2020, vol. 9, no. 2, pp. 756-762.

Translated by B. Gilbert 